\title{
Sivistys ja tasa-arvo
}

\author{
Jarmo Tarkki
}

\author{
"Tieto on demokraattisin vallan lähde". (Alvin Toffler, \\ 1991) Silloin, kun yhteiskunnassa pyritään kätkemään \\ tietoa tai sen hankkiminen tehdään vaikeaksi, on \\ kysyttävä, kenen edut ovat vaarassa, jos tietoa olisi \\ saatavissa.
}

$\mathrm{J}_{k}$

ohann Wolfgang von Goethe kirjoitti: "Miään ei ole niin vaarallista kuin aktiivinen tietämättömyys. "Pari sataa vuotta myöhemmin Martin Luther King, Jr. muotoili ajatuksen näin:

"Mikään maailmassa ei ole vaarallisempaa kuin aito tietämättömyys ja tunnontarkka typeryys." (King, 1963)

Tietämättömyyden lisääntyessä dogmaattisuus saavuttaa suosiota, tietämättömyyteen perustuva dogmaattisuus taas johtaa usein fanaattisuuteen, epätoivoon ja väkivaltaan. Mitä vähemmän tällaista tietämättömyyttä ja "tunnontarkkaa typeryyttä“ esiintyy, sitä turvallisempi, tai vähemmän vaarallinen maailma on. Tietämättömyyden torjunta puolestaan edellyttää mahdollisuuksien tasa-arvoa itsensä sivistämiseen.

Joitakin vuosia sitten USA:ssa ilmestyi kirja nimeltä "The Dictionary of Cultural Literace" (Hirsch, 1993) alaotsikolla: "Mitä jokaisen amerikkalaisen kuuluu tietää. Ajatuksena oli nimetä ne asiat, jotka jokaisen itseään sivistyneenä pitävän amerikkalaisen ihmisen tulisi tietää. Kerrankin oli uskallettu sanoa, mitä pitää tietää ja jopa kirjaimellisesti luetteloitu ne asiat, jotka sivistyneen ihmisen tulisi hallita.
Sivistymättömyydestä, tietämättömyydestä ja typeryydestä on USA:ssa ja monissa muissakin maissa tullut yleisesti hyväksyttävä asia. Näyttää siltä, että ollaan menossa kohti yhteiskuntaa, jossa kaikki on ymmärrettävää, eikä ainoastaan ymmärrettävää, vaan myöskin hyväksyttävää. Kirjan tekijät reagoivat tähän ajassa liikkuvaan myrkylliseen, tietämättömyydellä suorastaan ylpeilevään "Zeitgeistiin." Nähtäväksi jää, onko tällaisella kirjalla mitään vaikutusta.

Kirjan lista on kattava. Sen tiedot omaavan voidaan hyvällä syyllä olettaa olevan sivistynyt. Kirjan tekijöiden mukaan sivistynyt ihminen tietää esimerkiksi, keitä olivat Vidkun Quisling, Faustus, El Greco, mikä on absoluuttinen nollapiste, tai mikä on Valhalla, tabula rasa, mitä tarkoittaa nom de plume, jne.

Mutta mitä hyötyä on sivistyksestä merkityksessä "tietää jotakin"? Miksi emme kaikki eläisi sivistymättöminä moukkina? Miksi meidän pitäisi olla huolissamme siitä, että sivistymättömyydestä on tulossa yleisesti hyväksyttävä asia? Takaako sivistys aristotelisen elämän tarkoituksen, summum bonumin, sen kaikkein korkeimman hyvän eli onnellisuuden? Tuskinpa, mutta kääntäen voidaan sanoa, että sivistymättömyys ei takaa onnellisuutta sekään. ${ }^{1}$ 


\section{A R T I K K E L I T}

Samalla tavalla kuin kysymme, mitä hyötyä on sivistyksestä, voisimme kysyä, mitä hyötyä on kauneudesta, koskemattomasta luonnosta tai vaikkapa joutsenista. Vaikka sivistyksen hyödyllisyys on vaivoin filosofisesti perusteltavissa, uskallan veikata, että se on hyvä ja tavoiteltava asia. Se ainakin avaa ihmiselle mahdollisuuksien portteja, kun taas sivistymättömyys rajoittaa mahdollisuuksia.

Sivistys merkitsee tietämättömyyden torjumista. Sokrateen mukaan paha ihminen ei ole mitenkään ontologisesti paha, vaan hän on tietämätön. Vähemmän tietämätön ihminen on vähemmän paha, paljon tietävä on siis jopa hyvä, Sokrateen mukaan. Jos sivistys on näin ollen hyvä ja tavoiteltava asia, joka avaa ihmiselle mahdollisuuksien portteja, pitäisikö yhteiskunnan taata kaikille tasa-arvoiset mahdollisuudet sivistyä?

\section{TASA-ARVON KÄSITE}

Käsitteen "tasa-arvo" olemassaolo on selvää, mutta sen tarkka merkitys ei ole. Koska tarkkaa määritelmää ei keskustelussa tavallisesti esitetä, seurauksena on ollut käsitteellistä ja asiasisällöllistä epävarmuutta. Oletuksena on ollut, että kaikki jotenkin intuitiivisesti ymmärtävät ja tietävät, mitä tasa-arvolla tarkasti ottaen tarkoitetaan. ${ }^{2}$

Tasa-arvo sinänsä on vailla merkitystä ilman siihen liitettyä ajatusta kohtelusta. Ihmiset eivät vain oleskele tasa-arvoisesti. Emme siis voi puhua tasaarvosta sinänsä, vaan tasa-arvoisesta kohtelusta tai sen puutteesta.

Toiseksi ei ole mielekästä puhua tasa-arvoisesta kohtelusta yleisessä merkityksessä. Sen sijaan voimme puhua jonkun henkilön tai henkilöiden tasa-arvoisesta kohtelusta jollakin tietyllä rajatulla elämän alueella. On merkityksetöntä sanoa esimerkiksi, että naiset ovat miesten kanssa tasa-arvoisia tai, että suomalaiset ovat keskenään tasa-arvoisia. Tasa-arvoon liittyy aina jonkun henkilön tai henkilöiden kohtelu jollakin tietyllä rajatulla alueella.

Esimerkiksi voidaan sanoa, että henkilöt A ja B

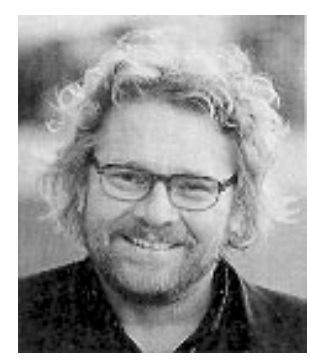

Jarmo Tarkki

ovat tasa-arvoisia työpaikan $\mathrm{x}$ hakijoita. Sen sijaan ei ole mielekästä sanoa, että A ja B ovat tasa-arvoisia työpaikan hakijoita ilman lisämäärettä "työpaikan x suhteen".

Ehdotan tasa-arvon määritelmäksi:

A:n ja B:n voidaan sanoa olevan keskenään tasa-arvoisia jollakin rajatulla alueella $\mathrm{C}$, jos A:lla on samat C:n kannalta merkitykselliset ominaisuudet kuin B:llä ja heitä kohdellaan alueella $\mathrm{C}$ samanlaisella tavalla.

Epätasa-arvon määritelmä kuuluisi näin ollen seuraavasti:

A:n ja B:n voidaan sanoa olevan keskenään epätasa-arvoisia jollakin rajatulla alueella $\mathrm{C}$, jos ei ole niin, että A:lla on samat C:n kannalta merkitykselliset ominaisuudet kuin B:llä tai heitä ei kohdella alueella C samanlaisella tavalla.

Merkittävää epätasa-arvoisuuden määritelmässä on, että vaikka henkilöitä A ja B kohdeltaisiin alueella $C$ samanlaisella tavalla, he eivät ole tasaarvoisia mikäli A:lla ja B:llä ei ole C:n kannalta samat merkitykselliset ominaisuudet.

\section{TASA-ARVO -KÄSITTEEN MERKITYKSEN MUUTTUMINEN}

Tasa-arvokeskustelun painotuserot ovat vaihdelleet eri aikakausina. Platon ja Aristoteles olivat huolissaan epätasa-arvoisten henkilöiden tasaarvoisesta kohtelusta. He pitivät tätä oikeudenmukaisuutta syvästi loukkaavana asiana. Tänä päi- 
vänä tästä aiheesta ei puhuta juuri lainkaan. Ihmiset ovat sen sijaan huolestuneita tasa-arvoisina pidettyjen ihmisten ostensiivisesti epätasaarvoisesta kohtelusta.

Tasa-arvon ja oikeudenmukaisuuden keskinäiset suhteet voidaan esittää seuraavasti:

\section{Oikeudenmukainen tasa-arvo:}

1. Tasa-arvoisten tasa-arvoinen kohtelu

2. Epätasa-arvoisten epätasa-arvoinen kohtelu

\section{Epäoikeudenmukainen tasa-arvo:}

1. Tasa-arvoisten epätasa-arvoinen kohtelu

2. Epätasa-arvoisten tasa-arvoinen kohtelu

Yhtä mieltä voidaan olla siitä, että tasa-arvoisiksi arvioituja ihmisiä on kohdeltava tasa-arvoisesti jonkin tietyn asian suhteen. Samoin voidaan olla yhtä mieltä epätasa-arvoisten epätasa-arvoisesta kohtelusta.

Vaikeampaa on hyväksyä tasa-arvoisina pidettyjen ihmisten epätasa-arvoista kohtelua. Suurin osa ihmisistä kokee tämän oikeudenmukaisuutta loukkaavana. Käydyt tasa-arvokeskustelut keskittyvät tavallisesti juuri tähän epäoikeudenmukaiseksi koettuun asiantilaan.

Matteuksen evankeliumin kirjoittajan raportti (Matt. 20:1-15) Jeesuksen vertauksesta viinitarhan työmiehistä on hyvä esimerkki Platonin ja Aristoteleen esittämästä huolenaiheesta. Perheenisäntä palkkasi työmiehiä viinitarhaansa. Jotkut palkattiin töihin heti aamulla, toiset puoleltapäivin, ja jotkut alkuiltapäivästä, toiset myöhäisiltapäivästä ja jotkut vasta hetkeä ennen työpäivän päättymistä. Kuitenkin isäntä maksoi saman palkan kaikille, yhden denarin. Oliko isäntä oikeudenmukainen?

Jeesuksen vertauksen ymmärtämisen edellytys on esitetyn tilanteen epäoikeudenmukaisuuden käsittäminen. Viinitarhan työmiehet tekivät eri pituiset työpäivät ja kuitenkin kaikille maksettiin sama palkka. Oikeudenmukaisuutta loukkaa sekä samasta työpanoksesta maksettu eri palkka että eri työpanoksista maksettu sama palkka.

\section{BABEUF JA TASA-ARVOISTEN MANIFESTI}

Ranskan vallankumouksen johtajan François Noël Babeufin (1760-97) tasa-arvoisten manifesti ${ }^{3}$ on yksi huomattavin samanlaistamistasa-arvoajattelun ilmaus. Babeufin mukaan tasa-arvo on "luonnon ensimmäinen mielihalu, ihmisen ensimmäinen tarve, kaikkien laillisten yhteiskuntien koossapitävä voima.“ Ikää ja sukupuolta lukuunottamatta kaikki ihmisten väliset erot tuli hävittää. Kaikkien olisi syötävä samaa ruokaa, koska kaikilla on samanlainen vatsa. Taiteet tuli hävittää, samoin kuin urheilukilpailut. Niissä paljastuisi ihmisten välisiä eroja. Koulu- ja yliopistoarvosanat tuli niin ikään poistaa.

Babeufin ajattelussa näkyy merkittävällä tavalla tasa-arvokäsitteen ymmärtäminen eroavaisuuksien eliminoimisena eikä mahdollisuuksien luomisena, kaikenlaisten tasa-arvoesteiden eliminoimisena tai minimoimisena. ${ }^{4}$ Kaikenlainen erilaisuus nähtiin apriorisesti tuomittavana, tasa-arvoisuuden toteutumisen esteenä.

Koska tasa-arvoa pidettiin korkeimpana mahdollisena arvona, kaiken vapauden ja hyvinvoinnin perustana, Babeuf ja hänen kumppaninsa olivat valmiit maksamaan kaikkien tasa-arvosta minkä hinnan hyvänsä. Yksi heidän realistisimmista ajatuksistaan oli, että ihmiset eivät tulisi vapaaehtoisesti hyväksymään tätä kaikkien tasa-arvoa. Tiukimmat vastustajat tuli tappaa. Tosin verenvuodatus tulisi kestämään ainoastaan kolme kuukautta.

Suomalaista tasa-arvopolitiikkaa ei ole koskaan eksplisiittisesti muotoiltu näin räikeästi, mutta uskallan väittää, että meillä harjoitetussa politiikassa on monia babeuvistisia piirteitä. Tasa-arvoa pidetään merkittävänä yhteiskunnallisena arvona, jonka toteuttamisesta ollaan valmiita maksamaan korkea hinta.

Babeuvististen ihanteiden mukaan sivistyksen pitäisi olla jaettu "tasan". Samoin kuin liiasta ahkeruudesta ja työinnosta kärsiviä tuli hillitä tasaarvon nimessä, liian sivistyneitä tuli hillitä ja kovakalloisia kannustaa. 
Babeufin ajatukset ovat idealistisia ja epärealistisia. Terho Pursiaista mukaillen voidaan sanoa, että ihmistä parempien ihanteiden ajamista ei pitäisi edes yrittää. Babeufin ajatukset ovat ihmistä parempia, toteuttamiskelvottomia ja suorastaan harmillisia. Täydellisen tasa-arvoinen yhteiskunta babeuvistisessä merkityksessä vaikuttaa varsin vastenmieliseltä paikalta.

Babeufin ajattelun juuret löytyvät Ranskan vallankumouksen aikaisesta luonnonromanttisesta ihmiskäsityksestä. Yksi tämän ajattelun näkemyksistä oli, että kaikki ihmiset voivat oppia kaikkia asioita. Ihmiset syntyvät samanlaisina, heitä opettamalla luodaan tasa-arvoinen yhteiskunta, jossa kaikki ovat yhtä sivistyneitä. Tällaisia näkökohtia toi esille esimerkiksi Jean-Jacques Rousseau. ${ }^{5}$

Rousseaulais-babeuvistiset ajatukset maustettuina viimeisimmillä kasvatuskeksinnöillä levisivät käytännön koulutukseen, yllättävää kyllä, varsinaisesti vasta 1960-luvulla, jolloin niitä alettiin noudattaa Yhdysvaltojen ja Englannin julkisissa kouluissa. Suomessa näitä ajatuksia alettiin toteuttaa laajamittaisesti 1970-luvulla. Myöhemmin tasa-arvoista kasvatusihannetta pyrittiin toteuttamaan poistamalla tasokurssit. Kaikille opetettiin kaikkea. Mutta koska kaikki eivät ole oppineet kaikkea ratkaisuksi on ehdotettu mm. ylioppilaskirjoitusten poistamista. Nyt näistä rousseaulais-babeuvistisista ajatuksista ollaan huonojen kokemuksien vuoksi luopumassa niin USA:ssa kuin Englannissakin, mutta ei vielä meillä. ${ }^{6}$

\section{ERILAISUUS JA ERIARVOISUUS}

Suomalaisessa tasa-arvokeskustelussa on usein pidetty selvänä sitä, että käsite "tasa-arvo" merkitsee jonkinlaista samanlaisuutta. Tätä ei kuitenkaan ole tavallisesti lausuttu selvästi julki. Ilmaisut ovat yleensä sellaisia kuten "ihmiset joutuvat eriarvoiseen asemaan, jos tehdään niin ja niin." Eriarvoistavat toimet tuomitaan apriorisesti.

Erilaisuus ja eriarvoisuus on nähty tasa-arvon vihollisena. Huomioimatta jää tavallisesti, että ihmiset todellisuudessa ovat taidoiltaan, tiedoil- taan ja monien muiden ominaisuuksiensa suhteen erilaisia ja siten myös eriarvoisessa asemassa. Useimmat meistä eivät osaa lentää Finnairin suuria lentokoneita. Useimmat meistä eivät myöskään osaa toimia sydänkirurgeina, Nokian johtajana tai ohjata sukellusveneitä. Kaikista meistä ei pituutemme vuoksi tule hyviä koripallonpelaajia tai sirkuskääpiöitä.

Kysymys ei ole siitä, olemmeko erilaisia vai emme, vaan siitä, kuinka paljon me poikkeamme toisistamme eri ominaisuuksien suhteen. Identtiset kaksoset eivät poikkea ulkonäkönsä puolesta mutta heidän kokemusmaailmansa on joka tapauksessa erilainen. Ihminen ei näe pelkästään silmillään vaan kaikilla niillä elämänkokemuksillaan, joita hänellä on. Eriarvoisuus seuraa monista asioista, mm. erilaisuudesta. Koska me olemme erilaisia ja koska eriarvoisuus seuraa osittain myös erilaisuudesta, kysymys ei ole siitä, olemmeko eriarvoisia vai emme, vaan siitä, kuinka eriarvoisia olemme.

Käytännössä erilaisuuden ja eriarvoisuuden pelko on ilmennyt siten, että esimerkiksi eripalkkaisuutta yleensä ja samantyyppisten työtehtävien kohdalla erityisesti on pidetty ongelmallisena, ikään kuin ihanteena olisi kaikille sama palkka riippumatta taidoista tai työpanoksesta. Jyrkällä veroprogressiolla ja tulonsiirroilla meillä on lähestytty universaalipalkkamallia - bruttopalkkojen erilaisuudesta huolimatta lopulta kaikilla on lähestulkoon sama palkka.

Jokaisen ihmisen työpanos on arvokas, mutta toisten tiedot ja taidot ovat pitkällä koulutuksella ja kokemuksella ansaittuja, kun taas toisilla näitä pitkälle kehitettyjä valmiuksia ei ole joko siksi, että niitä ei ole vielä ehditty hankkia tai sitten niitä ei pystytä tai haluta hankkia. Vaatimattomamman valmiustason työn tekijät ovat helpommin korvattavissa kuin vaativan työn tekijät. Melkein kuka tahansa voi toimia hampurilaisenkääntäjänä, mutta kuka tahansa ei voi toimia sydänkirurgina.

Kohtuullinen eripalkkaisuus on elävän yhteisön elinehto. Tasa-arvon nimissä esitetyt samapalkkaisuusideat koituisivat toteutuessaan viime kä- 
dessä kaikkien tappioksi, kuten esimerkiksi Kiinassa on viime vuosina huomattu. Toisaalta kohtuuton eripalkkaisuus johtaa yhteiskunnallisiin levottomuuksiin ja turvattomuuteen. Kohtuullisen ja kannustavan eripalkkaisuuden ylläpitäminen, samalla mielessäpitäen erityisesti kaikkien vähäosaisten aseman parantaminen, edellyttää taitavaa yhteiskunnallista suunnittelua.

Taustalla samalaistamistasa-arvopolitiikassa on ollut ajatus siitä, että kun kaikilla ihmisillä kaikki asiat ovat olennaisesti samalla tavalla, tasa-arvo toteutuu. Samanlaistamistasa-arvopolitiikka on taas johtanut lisääntyneeseen yleiseen keskinkertaistumiseen. Meitä "tasoitetaan" tasa-arvoisuuteen. Esimerkiksi lahjakkaiden oppilaiden kouluja, puhumattakaan varsinaisista eliittikouluista, joihin vain varakkaat voisivat lähettää lapsensa, ei Suomessa koeta tänä päivänä hyväksyttävinä. Urheilun kohdalla tässäkin tehdään kivuttomia poikkeuksia. ${ }^{7}$

Siitä, että jokin asia on tietyllä tavalla, ei seuraa, että sen pitäisi olla niin (Sein und Sollen -problematiikka). Ihmisten välinen erilaisuus voitaisiin yrittää poistaa ja kaikki erot tasoittaa Babeufin ohjelmajulistuksen mukaisesti. Kurt Vonnegutin satiiri "Harrison Bergeron" kertoo tulevaisuuden täydellisestä tasa-arvoyhteiskunnasta. Se antaa hyvän kuvan siitä, miltä tällainen yhteiskunta voisi näyttää. ${ }^{8}$

Erilaisuus johtaa usein eriarvoisuuteen ja eriarvoisuus erilaisuuteen. En kuitenkaan voi hyväksyä tätä sinänsä ongelmaksi. Mistä on tullut sellainen ajatus, että eriarvoisuus on ongelma? Eriarvoisuus voidaan ymmärtää oikeudenmukaisena tai epäoikeudenmukaisena. Oikeudenmukainen eriarvoisuus, esimerkiksi se, että minulla ei ole oikeutta toimia Finnairin lentokapteenina, ei ole ongelma. Epäoikeudenmukainen erilaisuudesta seurannut eriarvoisuus, kuten esimerkiksi aikanaan Etelä-Afrikan apartheid -politiikka, ansaitsee oikeutetun tuomion. Tärkeätä on ymmärtää, että kaikki eriarvoisuus ei ole epäoikeudenmukaista.

Ihmiset syntyvät maailmaan samanarvoisina, mutta eivät tasa-arvoisina merkityksessä samanlaisi- na. Me olemme itsekukin omien perintötekijöidemme "uhreja." Erilaiset perintötekijät antavat meille erilaisia valmiuksia. Ihmisten erilaisuudesta ja moninaisuudesta muodostuu elämän tosiasiallinen rikkaus. Erilaisuutta ei kuitenkaan saa käyttää minkään ihmisryhmän syrjintään, kuten valitettavan usein on historian aikana käynyt.

Mitä sivistyneempi ja valistuneempi yhteiskunta on, sitä paremmin se sietää keskuudessaan syrjinnästä ja sorrosta vapaata erilaisuutta. Erilaisuuteen kuuluu eri rotuisia ihmisiä, eri uskontoja edustavia ihmisiä, erilaisia taitoja ja tietoja omaavia yksilöitä. Mitä vähemmän sivistynyt ja valistunut yhteiskunta on, sitä enemmän siellä pyritään yhdenmukaistamaan ihmisiä ja sortamaan niitä, jotka eivät pysty tai halua konformoitua. ${ }^{9}$ Aito tasa-arvo johtaa mahdollisuuksien tasa-arvon toteutumiseen, ei saman lopputuloksen varmistamiseen.

Kansanvalistusseuran uudessa helmikuun manifestissa tämä on ilmaistu osuvasti: "Varjelkoon hän moniarvoisuutta. Siitä syntyy sivistys." Mutta voiko moniarvoisuutta olla ilman eriarvoisuutta? Toivottavaa on, että kaikkia rakentavaa eriarvoisuutta voisi olla ilman kenenkään epäoikeudenmukaista syrjintää.

\section{EPISTEEMINEN EGALITARISMI}

Mikäli sivistyksellä ymmärretään ihmisten tiedollista, eettistä ja esteettistä kehitystä, silloin voitaisiin ajatella, että tasa-arvo sivistyksen kohdalla merkitsisi jonkinlaista "episteemistä egalitarismia," tietämisen tasa-arvoa. ${ }^{10}$

Käsitteellä "episteeminen egalitarismi" tarkoitan sitä aikamme ilmiötä, missä kaikkien ihmisten kaikki näkemykset kaikista asioista pyritään hyväksymään yhtä arvokkaina. Tällainen ajattelu on varsin pitkälle edennyt niissä yhteiskunnissa, joissa erilaisuutta on pyritty arvostamaan.

Esimerkkinä voisi olla USA, jossa monet kohteliaat keskustelut ovat pelkästään lausuntojen antamista. Näin tehdään erityisesti proverbiaalisilla cocktail-kutsuilla, joilla ei pidetä sopivana toisten kehnostikaan perusteltujen mielipiteiden 
arvostelua. Perustellut ja rationaalisen ajattelun alapuolella olevat perustelemattomat mielipiteet pannaan luvattoman usein samalle viivalle.

Tällainen hymistelykeskustelu on erityisen suosittua uskonnollisista ja poliittisista aiheista keskusteltaessa. Jotkut joidenkin ihmisten mielipiteet ja käsitykset näistä aiheista ovat huonosti perusteltuja tai jopa vailla minkäänlaisia rationaalisia elementtejä. Mutta teeskentelevä hienotunteisuus ja poliittinen korrektius vaatii hymistelyä. Tällaisessa "sivistyksen" tilassa, jossa episteeminen egalitarismi, mielipiteiden tasa-arvo vallitsee, kaikki on totta ja relevanttia.

Esitin kerran hyvin koulutetulle ystävälleni kutsun osallistua luennolle, jossa käsiteltäisiin menninkäisten sielunelämään liittyviä ongelmia. Hän otti asian tosissaan ja suhtautui esitelmän aiheeseen kuin mihinkä hyvänsä legitiimiin luentoon. Hänen selatessaan kalenteriaan ilmoitin, että kyseessä oli vitsi. Ainakin minun mielestäni.

Yhteiskunnassa, jossa vallitsee mielipiteiden tasaarvo, tila, jossa kaikki kaikkien mielipiteet noteerataan perusteluista piittaamatta yhtä arvokkaina, vallitsee epätoivottu episteemisen egalitarismin tila. Viime kädessä noin toimiva yhteiskunta halvaantuu toimintakyvyttömäksi. Kaikesta tulee suhteellista, argumentteja ei voi ikään kuin ripustaa mihinkään.

Mutta kuka sitten erottaisi perustellut hyvät mielipiteet perustelemattomista ja kelvottomista? Viime kädessä hyvin koulutetut ja sivistyneet ihmiset joutuvat itse tekemään nämä päätökset. Tähän tarvitaan valmiuksia. Ihmisille on luotava mahdollisuudet itse sivistää itseänsä ja hankkia tarvittavat tiedot erottelun tekemiseksi.

Kouluilla ja yliopistoilla on ratkaiseva merkitys tässä prosessissa. Tärkeää on omaksua kriittisen ajattelun menetelmät. Pelkkä tieto sinänsä ei riitä, vaan vasta sen kriittinen ja rakentava käsittely antaa meille todelliset välineet asioiden luonteiden ymmärtämiselle. ${ }^{11}$

Esimerkin voimme ottaa jokapäiväisistä uutisaiheista. MTV3:n internetissä oleva uutispalvelu tiesi kertoa 6.10.1999: "Rasististen rikosten määrä kasvanut". ${ }^{2}$ Artikkelin kirjoittaja ei kiinnitä huomiotaan siihen tosiseikkaan, että otsikko on harhaanjohtava. Tekstistä käy valistuneelle lukijalle selväksi, että rasistiset rikokset eivät välttämättä ole lisääntyneet ollenkaan, vaan niistä poliisille tehtyjen raporttien lukumäärä. Tätä rivienvälistä tietoa ei artikkelissa ole mainittu, vaikka se onkin ratkaisevan tärkeä.

Sivistyksen kannalta tasa-arvoinen yhteiskunta on sellainen, jossa jokaisella sivistystä haluavalla on siihen realistiset mahdollisuudet. Tämän on katsottu käytännössä merkitsevän maksutonta koulutusta.

Ilmaisu "maksuton koulutus" on sinänsä harhaanjohtava, koska sellaista ei ole olemassakaan. Kaikki koulutus maksaa. Sen maksavat joko veronmaksajat tai sitten koulutettavat itse. Pitäisikö tasaarvoisten sivistysmahdollisuuksien nimessä kaikilla olla yhteiskunnan maksama koulutus?

Sellainen yhteiskunta, jossa vain varakkailla tai oikeakätisillä savolaisilla miehillä olisi oikeus opiskella oikeustieteitä, olisi epäoikeudenmukaisen epätasa-arvon yhteiskunta. Jos sen sijaan esitetään tiettyjä yleisiä pääsyvaatimuksia esimerkiksi yliopistoon pyrkiville (numerus clausus), kysymyksessä on oikeudenmukainen tasa-arvoinen kohtelu siitä huolimatta, että kaikilla ei ole joko taitojen, tietojen, kykyjen tai muiden seikkojen vuoksi yhtäläisiä mahdollisuuksia.

Opiskelun tulisi kuitenkin aina maksaa opiskelijalle itselleen, mutta maksu ei saa koskaan muodostua ylivoimaiseksi esteeksi kouluttautumiselle. Opiskelumotiivia parantavat taloudelliset, oikein viritetyt porkkanat kun taas porkkanaton järjestelmä, mikä meillä nyt käytännössä vallitsee, ei sisällä riittäviä kannusteita tehokkaalle työskentelylle. Nyt opiskeluajat venyvät meillä tavattoman pitkiksi verrattuna moniin muihin maihin. ${ }^{13}$

Perustellusti voidaan esittää, kuten esimerkiksi feministi ja yhteiskuntakriitikko Onora O'Neill on esittänyt (O'Neill, 1977), että taloudelliset ja muut ihmisten olosuhteet eivät koskaan luo yhtäläisiä realistisia ja tasa-arvoisia mahdollisuuk- 
sia kaikille. Opiskelumenestykseen vaikuttavat monet eri tekijät, esimerkiksi kotiolot, huoltajien asenne, kotipaikka jne. Onko nyt sitten kysymyksessä yhteiskunnallista korjausta kaipaava epäreilu tilanne vai korjausta kaipaamaton onneton asioiden tila? ${ }^{14}$

O’Neill, joka edustaa vahvaa mahdollisuustasaarvopoliittista näkemystä, haluaa luoda olosuhteet, jossa pyrittäisiin takaamaan mahdollisimman samanlainen lopputulos kaikille. Minä en. En halua asua maassa, jossa kaikki ihmiset olisivat olennaisesti samanlaisia. Tämä ei tarkoita sitä, etteikö kaikkia ihmisiä pitäisi pyrkiä tukemaan ja kannustamaan kaikilla mahdollisilla keinoilla toteuttamaan omia kykyjään ja unelmiaan. Maailma on yksinkertaisesti rakennettu siten, ettei elämässä menestymiseen ole mitään oikotietä. $\mathrm{Ne}$, jotka ovat tiedollisesti sivistyneempiä, ovat paremmissa lähtöasemissa kuin vähemmän sivistyneet.

\section{TASA-ARVO JA EKONOMIAIGNORANTIA}

Tiedollisesti paremmassa asemassa olevien ihmistien pärjääminen näkyy hyvin esimerkiksi taloudellisen osaamisen kohdalla. Olen usein hämmästellyt sitä, että kaikkein perustavinta laatua olevat talouden hoitoon liittyvät asiat ovat monelle epäselviä. Omien kyselyjeni perusteella useat veronmaksajat eivät esimerkiksi tiedä, mitä tarkalleen ottaen tarkoittaa verovähennysoikeus. Taloussivistys on meillä surkeassa tilassa. Tavatonta ei ole taloudellisista asioista tietämättömyydellä ylpeilykään. Sivistyneen ihmisen yhtenä merkkinä ei yleisesti pidetä taloudellisten asioiden osaamista. ${ }^{15}$

Suomessa on vapaa, tosin vahvasti kontrolloitu, markkinataloussysteemi. Kaikki ihmiset käyttävät joka päivä rahaa. Mutta opetetaanko meille kouluissa rahankäyttöä, kuinka asunto vuokrataan, tai kuinka sellainen ostetaan? Opetetaanko meille kouluissa, miten osakekauppaa käydään pörssissä? USA:ssa monissa kouluissa lapsilla on omat "osakesalkkunsa". Nämä leikkisalkut tutustuttavat koululaiset siihen, miten markkinataloussysteemi toimii.
En tarkoita tällä sitä, että kaikkien ihmisten tulisi ryhtyä osakesäästäjiksi. Mutta kuinka tavalliset suomalaiset pärjäävät "talouspelissä,“ jos kerran pelin säännöt ovat vain harvojen ihmisten tiedossa?

On syytä kysyä, kenen etuja palvelee taloudellisen sivistyksen alhaisen tason ylläpitäminen? Tasaarvoisessa yhteiskunnassa tulisi huolehtia kaikenpuolisesta ihmisten välisestä mahdollisuuksien tasa-arvosta. Miksi juuri tällä kohtaa meillä on suurta eriarvoisuutta?

\section{ORWELL, HUXLEY JA DEMOKRATIA}

Alvin Tofflerin mukaan "Tieto on demokraattisin vallan lähde“. (Toffler, 1991) Silloin, kun yhteiskunnassa pyritään kätkemään tietoa tai sen hankkiminen tehdään vaikeaksi, on kysyttävä kenen edut ovat vaarassa, jos tietoa olisi saatavissa. Tieto on "alituinen uhka vallanhaltijoille, jokainen vallan haltija haluaa valvoa valtapiirissään tiedon määrää, laatua ja jakelua.” (emt)

Neil Postman kirjoitti tästä osuvasti vertaillessaan toisiinsa kahta tulevaisuudesta kirjoittanutta ajattelijaa, Aldous Huxleyta ja George Orwellia:

Orwell pelkäsi niitä, jotka julistaisivat kirjat pannaan. Huxley puolestaan pelkäsi, että ei olisi mitään syytä minkään kirjan pannaan julistamiselle, koska kukaan ei haluaisi lukea kirjoja. Orwell pelkäsi niitä, jotka riistäisivät meiltä mahdollisuuden saada oikeita tietoja. Huxley pelkäsi niitä, jotka jakaisivat niin valtavasti tietoa, että meistä tulisi passiivisia ja vain omista asioistamme välittäviä, itsekkäitä ihmisiä. Orwell pelkäsi, että totuus kätkettäisiin meiltä. Huxley pelkäsi, että totuus hukutettaisiin mitättömyyden mereen. Orwell pelkäsi, että meistä tulisi sidottu ja valvottu kulttuuri. Huxley pelkäsi, että meistä tulisi triviaali, yhdentekevä kulttuuri. Orwell pelkäsi, että se, mitä me vihaamme, tuhoaa meidät. Huxley pelkäsi, että se, mitä me rakastamme, tuhoaa meidät. (Postman, 1985) 
Postmanin mukaan Huxley näyttää osuneen oikeaan. Informaatioyhteiskunnassa sivistystä ei ole tiedon mahdollisimman suuren määrän hallitseminen, vaan oikean ja relevantin tiedon löytäminen ja hallitseminen. On tapahtunut se, minkä Huxley ennusti, nimittäin, että tietoa on nyt niin paljon, että relevantti hukkuu irrelevantin joukkoon. Missä meitä opetetaan sivistämään itseämme relevantin tiedon hankkimiseen? Ratkaiseva osa oikeata sivistystä tänä päivänä on sen hallitsemista, että pystyy erottamaan relevantin irrelevantista. $^{16}$

Tietämisen suhteen tasa-arvoinen yhteiskunta on suuri haaste edustuksillisille demokratioille, varsinkin, jos yleinen tietäminen on korkealla tasolla. On turha epäillä, etteivätkö nykyisten kansanvaltaisten maiden päätöksentekijät käyttäisi hyväkseen ihmisten tietämättömyyttä. Kansan tietämättömyys on vahva ase kyynisen poliitikon arsenaalissa. Mutta mitä kansanvaltaa on sellaisessa maassa, jossa äänestäjäkunta on valistumatonta?

Sivistyksellinen tasa-arvo tarkoittaa sitä, että kaikilla ihmisillä tulisi olla realistiset mahdollisuudet itsensä sivistämiseen. Tämä tarkoittaa sitä, että tietoa tulisi olla kohtuullisen helposti saatavilla, että koulutusjärjestelmä on riittävän kattava ja tehokas niin, että se antaa ihmisille itselleen valmiudet tiedon hankintaan. Tiedon määrällä sinänsä ei ole ratkaisevaa merkitystä vaan sen laadulla.

Lopulta kaikki on kiinni ihmisestä itsestään. Viime vuosina ei ole ollut muodissa korostaa ihmisen omaa aloitekykyä ja hänen vastuullisuuttaan. Ihmisen kohtalo on pikemminkin haluttu nähdä hänen ympäristössään, jonka kohtalokkaana vankina hän on. Uskomuksena on ollut marxilainen käsitys siitä, että ihminen muuttuu ympäristöä muuttamalla. Merkkejä tämän näkemyksen korostamisen heikkenemisestä on jo olemassa.

Tasa-arvoiset mahdollisuudet oman itsensä sivistämiseen eivät merkitse sitä, että tavoitteena olisi episteeminen egalitarismi, siis se, että lopulta kaikkien kaikki mielipiteet olisivat yhtä arvokkaita. Toivottavaa on, että toiset ovat toisten edellä sivistyksessä. Silloin on esimerkkejä, esikuvia ja tavoitteita niille, jotka eivät vielä ole sivistyksen aristokraatteja.

\section{HYVÄ ELIITTI}

Friedrich Nietzsche kuvaili Ranskan aristokraattien tappiota vertaamalla heitä Jaavan saarella kasvavaan Sipo matador -kiipeilijäkasviin. Tämä kasvi tarvitsee tuekseen isoja vahvoja tammipuita, joita pitkin se kiipeilee. Lopulta se saavuttaa sademetsien korkeimman kohdan. Vasta silloin se puhkeaa upeaan kukkaan.

Ilman tammipuita Sipo matador -kasvi ei voisi menestyä. Tammien hyvinvointi on siten Sipo matodor -kasvin hyvinvoinnin edellytys. Nietzschen mukaan Ranskan aristokraatit halveksivat ja laiminlöivät tammipuita, kansaa. Tästä johtui Ranskan vallankumous, jota Nietzsche inhosi yli kaiken. Samalla hän antoi nykyajan näkökulmasta melkoisen poliittisesti epäkorrektia kritiikkiä tasa-arvoajattelua vastaan:

Vihaan Rousseauta vielä VALLANKUMOUKSESSA: se on maailmanhistoriallinen ilmaus tälle idealistin ja CANAILLEN kaksinaisuudelle. Verinen farssi, jollaisena tämä kumous toteutui, sen 'epämoraalisuus' ei minua juuri liikuta: minä inhoan Rousseaun MORAALISUUTTA - niin sanottuja vallankumouksen 'totuuksia', joiden kautta se vieläkin vaikuttaa ja houkuttelee puolelleen kaiken lattean ja keskinkertaisen. Oppi tasa-arvosta!...Mutta vaarallisempaa myrkkyä ei ole: sillä se tosin NÄYTTÄÄ itsensä oikeudenmukaisuuden saarnaamalta, kun se todellisuudessa on oikeudenmukaisuuden LOPPU... "Samanarvoisille samanlaista, eriarvoisille erilaista" - se olisi todellista oikeudenmukaisuuden puhetta: sekä se mitä siitä seuraa: "Eriarvoisesta ei koskaan saa tehdä samanlaista." - Se, että tämä tasa-arvokäsitys toteutettiin niin raa'asti ja verisesti, soi tälle "modernille idealle" PAR EXCELLENCE eräänlaisen tulenhehkuisen sädekehän, niin että vallankumous on NÄYTELMÄNÄ vietellyt puolelleen jaloimpiakin sieluja. Tämä ei kuitenkaan ole mikään syy kunnioittaa sitä enää rahtuakaan. - Näen vain yhden, joka koki sen siten kuin 
se kuuluu kokea, INHOTEN - hän oli Goethe. (Nietsche, 1995)

Aristokratian häviön myötä yhteiskunnasta on tullut keskinkertaisuuden ruumiillistuma. Hyvä aristokratia, sellainen, jota Ranskan aristokratia ei enää edustanut, olisi myös tavallisen kansan etujen mukaista. Silloin meillä olisi sivistystä ja kulttuuria, jota voisimme yhdessä tavoitella. Nietzschen aristokraatit eivät halveksi ja laiminlyö tavallisia ihmisiä, vaan sivistävät kaikkia. Kyseessä on eräänlainen sivistyksellinen versio $\mathrm{Pa}$ reto -optimaalisuudesta.

Tämän päivän aristokraatti voi olla kuka tahansa oppinut ja oppimaan oppinut sivistynyt ihminen. Näiden sivistyneiden ihmisten joukko muodostaa hyvän yläluokan, jota muut ihmiset voivat jäljitellä. Tasa-arvon kannalta ratkaisevaa on, että kaikilla ihmisillä syntyperään tai varallisuuteen katsomatta on mahdollisuus siirtää itsensä tuohon moderniin eliittiin.

Quod bonum, felix faustumque sit!

\section{Lähteitä}

HIRSCH, Jr., E. D., Kett, Joseph F. and Trefil, James, The Dictionary of Cultural Literacy. 2nd ed., rev and updated. Boston: Houghton Mifflin, 1993

KING, Jr., Martin Luther, Strength to Love, Philadelphia: Fortress Press, 1963. pt. 4, ch. 3, p. 43

NIETZSCE Friedrich, Epäjumalten hämärä, eli, miten vasaralla filosofoidaan, suomentanut Markku Saarinen, Helsinki: Unio mystica, 1995, aph. 48, s. 106

O’NEILL, Onora (1977) "How Do We Know When Opportunities Are Equal", Feminism And Philosophy, toim. Mary Vetterling-Braggin, Frederick Elliston ja Jane English, Littlefield, Adams, \& Co

POSTMAN, Neil, Amusing Ourselves To Death: Public Discourse In The Age Of Show Business, New York, N.Y., Penguin Books, 1985, s. vii-viii.

TOFFLER, Alvin, Suuri käänne, suomentanut Heikki Eskelinen, Helsinki: Otava 1991, s. 43

\section{Viitteet}

1 Aristoteles olisi hyvinkin saattanut todeta, että sivistys, sikäli mikäli se on rationaalisuuden harjoittamista sen täyteen potentiaaliseen maksimiinsa, on avain onnellisuuteen. Kukin olio saavuttaa Aristoteleen mukaan summum bonumin tulemalla mahdollisimman täydellisesti siksi, mikä on ko. lajin kvidditeetti, se mikä tekee jostakin oliosta juuri sen, mikä se on. Esimerkiksi linnulle ominaista on lentely, kalalle uiskentelu. Onnellinen lintu on se, joka harjoittaa lentotaitojaan tullakseen yhä paremmaksi lentäjäksi, onnellinen kala on se, joka on tullut omien kykyjensä rajoille uintitaidoissa. Ihmisen kvidditeetti on rationaalisuus. Onnellinen ihminen on siten se, joka on järjen käytön harjoittamisessa saavuttanut mahdollisimman korkean asteen. Ks. Aristoteles, $\mathrm{Ni}$ komakhoksen etiikka, suomentanut selityksillä Simo Knuuttila, Helsinki: Gaudeamus, 1989.

2 Ks. lähemmin tasa-arvon käsitteestä Jarmo Tark$\mathcal{L}$ ki ja Tuulikki Petäjäniemi, Tasa-arvo: saavutuksia ja haasteita. Jyväskylä: Atena Kustannus Oy, 1998.

3 Tasa-arvoisten manifestin, "Manifeste des Egaux", 3 kirjoitti Sylvain Marechal (1750-1803) Babeufin ajatusten pohjalta

1 Mahdollisuuksien luominen, merkityksessä esteiden poistaminen, on usein hyvin konkreettista puuhaa. Esimerkiksi yksinhuoltajaisän tai -äidin lapsille pitäisi löytyä kohtuullinen päivähoitopaikka opiskelujen mahdollistamiseksi. Diskriminoivat pakolliset eläkeiät pitäisi poistaa, paljon puhuttu lasikatto pitäisi purkaa, jne.

5 Ks. esimerkiksi Rousseau, Jean-Jacques, Émile,

6 Pääministeri Tony Blair esitti koulureformiohjelO mansa vuoden 1999 maaliskuussa. Blairin huolena on ollut tietotason yleinen lasku koulukokeilujen myötä. Radikaalit uudistukset tänä päivänä merkitsevät pitkälti paluuta vanhoihin malleihin.

7 Omien rahojen käyttö esimerkiksi viinaan, tupakkaan ja purjeveneisiin on yhteiskunnallisesti hyväksyttyä. Sen sijaan omien lastensa eliittikoulutukseen varojensa sijoittamista ei pidetä hyväksyttävänä. Vastustus on aika ajoin käsittämättömän lujaa. Ks. esim. Heikki Patomäen artikkeli, "Uusliberalismi loi koulutusloukun“. Helsingin Sanomat, Vieraskynä 4.8. 1998.

Q Harrison Bergeron elää tulevaisuuden tasa-arvoYhteiskunnassa (vuotta 2081), jossa kaikki olivat vihdoin täysin tasa-arvoisia. Keskinkertaisuutta pidettiin korkeimmassa arvossa. Kukaan ei ollut toista älykkäämpi, kukaan ei ollut toista kauniimpi, voimakkaampi, tai nopeampi. Lahjakkuutta hillittiin korvassa olevalla radiohäirintälaitteella. Ks. Kurt Vonnegut, "Harrison Bergeron" kokoelmassa Welcome to the Monkey House, Falmonth: Triad, 1982, s. 19-25.

Q Huomattavan haasteen tälle näkemykselle esittää holokausti. Saksa, Euroopan yksi sivistyneimmistä valtioista, syyllistyi valtaviin systemaattisiin sortotoimenpiteisiin ja massamurhiin 1930- ja 1940 luvuilla. Ks. tästä esim. Arendt, Hannah, The Origins of Totalitarianism, New York: Harcourt Brace Jovanovich, 1973. Johtaako sivistys sittenkään oikeudenmukaisempaan yhteiskuntaan? Vai oliko Saksa tuol- 
11 Matteuksen evankeliumin käännöksessään Pentti Saarikoski viittasi Esko Haavan Matteuksen evankeliumin kommentaariin, joka oli hänen mielestään "asiaa tunteva" mutta "asiaa ymmärtämätön“. Tämän distinktion tekeminen on avain monien asioiden syvemmälle käsittämiselle. Asiantuntija ei siis välttämättä ole sama kuin asiaa ymmärtävä. Olettaa sopii niin ikään, että asioita ymmärtävät eivät aina ole asioita tuntevia. Ks. Evankeliumi Matteuksen mukaan, Helsinki: Otava, 1969, suomentanut Pentti Saarikoski, s. 7.

12 YLEn vastaava internet uutispalvelu syyllistyi samanlaiseen otsikointiin. "Rasistiset rikokset lisääntyneet puolella“.

13 Yhteiskunta voisi osallistua koulutuksen kustannuksiin esimerkiksi hyväksymällä opintolainojen takaisinmaksun täysimääräisenä verohyvityksenä (verokredittinä). Järjestelmässä olisi siten sekä keppi että porkkana. Nykyisessä "maksuttomassa“ järjestelmässä ei ole kumpaakaan.

14 Tristram Engelhardt on käyttänyt tätä mielenonnekkaan tai onnettoman (unfortunate) välillä. Se, että ihmisten välillä on suuriakin eroja, ei aina ole epäreilua. Usein kysymys on epäonnekkuudesta. Näiden, epäreilun ja onnettoman menestyksekäs erottaminen toisistaan on hyvän yhteiskunnan rakentamisen yksi perusedellytyksiä. Ks. esim. Engelhardt, H. Tristram, The Foundation Of Bioethics, 2nd ed., New York: Oxford University Press, 1996. John F. Kennedy lausui samasta asiasta: "Elämässä on aina epätasa-arvoa. Jotkut miehet kuolevat sodassa, jotkut haavoittuvat, toiset eivät koskaan lähde maastaan. Elämä on epäreilua." J.F. Kennedy, lehdistökonferenssi, 21.3. 1962

15 Sanomalehtien eri osien sivumäärät heijasta 1 vat tätä ajattelua. Helsingin sanomien erityissivuista urheilusivuja on yleensä eniten, vahvana kakkosena ovat kulttuurisivut ja kaukana perässä taloussivut. Ekonomiaignorantiaan on jo reagoitu. Leena Kerkelä ja Sirkku Määttä ovat aivan äskettäin julkaisseet kirjan 100 sanaa taloudesta (Edita 1999). Lisäksi sähköisissä tiedotusvälineissä on uusia, pelkästään taloutta käsitteleviä ohjelmia. hyvin esimerkiksi shakinpelaajista tehdyssä tutkimuksessa. Tutkimuksen mukaan hyvät shakinpelaajat miettivät suunnilleen yhtä monta siirtoa eteenpäin kuin huonot pelaajat. Ero hyvien ja huonojen välillä ei ollut siis siirtojen määrän hallinnassa, vaan niiden merkityksissä. Huonot pelaajat käyttävät aikaansa irrelevanttien siirtojen analyysin, hyvät pelaajat osaavat taitojensa vuoksi kiinnittää huomionsa relevantteihin siirtoihin. Katso Tiede 2000 2/1984, Pertti Saariluoma, "Miksi menetin kuningattaren?"

Artikkeli saapui 8.10.1999. Se hyväksyttiin julkaistavaksi 13.10. sekä artikkeliksi 8.11.1999.

\section{Lehtiä Kansanvalistusseuran sivistyspuusta}

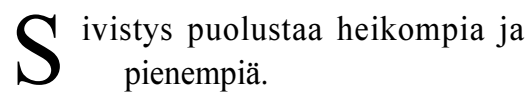

Taita tiedonpuusta matkasauvas.

OiliParjo

Pojat lukemaan!

Talo ilman kirjaa on kuin huone ilman ikkunaa.

Oppimisen alku on ihmettely.

ArjaPunula

Lukutaito on jokaisen maapallon asukkaan oikeus. IrinaKrohn

Vaikket voisikaan valaista koko maailmaa, sytytä kuitenkin oma kynttiläsi.

VïsastalainatenPaawoSalakka

Maailman muuttuminen alkaa itsensä velvoittamisesta (sanoi Santeri Alkio)

\section{MajaKaisaAula}

Ihminen on sivistynyt, kun hän on omaksunut kohtuullisen osan yhteisönsä kulttuuriperinnöstä ja kykenee hallitsemaan elämäänsä.

\section{OpetusministeriönhonnosKoulutusjatutkimus -sunnnitelmaksivuosille 1999-2004}

Yleissivistykseen kuuluvat niin tiedolliset valmiudet kuin eettinen ja esteettinen herkkyys, kehittynyt tunne-elämä, havainnoimisen ja kommunikoinnin taidot, työnteossa tarpeelliset perustaidot sekä taidot toimia yhteiskunnan jäsenenä.OpetusministeriönhonnosKoulutusjatutkimus-sunnnitelmaksivuosille1999-2004

www.kvs.fi/sivistyspuu 